\title{
1 Rapid carbon mineralization for permanent disposal of anthropogenic carbon dioxide
}

2 emissions

3 Juerg M. Matter ${ }^{1,2^{*}}$, Martin Stute ${ }^{2}$, Sandra Ó. Snæbjörnsdottir ${ }^{3}$, Eric H. Oelkers ${ }^{3,4,5}$,

4 Sigurdur R. Gislason ${ }^{3}$, Edda S. Aradottir ${ }^{6}$, Bergur Sigfusson ${ }^{6,7}$, Ingvi Gunnarsson ${ }^{6}$,

5 Holmfridur Sigurdardottir $^{6}$, Einar Gunnlaugsson ${ }^{6}$, Gudni Axelsson $^{8}$, Helgi A. Alfredsson ${ }^{3}$,

6 Domenik Wolff-Boenisch ${ }^{3,9}$, Kiflom Mesfin ${ }^{3}$, Diana Fernandez de la Reguera Taya ${ }^{2}$,

7 Jennifer Hall ${ }^{2}$, Knud Dideriksen ${ }^{10}$, Wallace S. Broecker ${ }^{2}$

$9{ }^{1}$ Ocean and Earth Science, University of Southampton, UK

$10{ }^{2}$ Lamont-Doherty Earth Observatory, Columbia University, USA

$11{ }^{3}$ Institute of Earth Sciences, University of Iceland, Iceland

$12{ }^{4}$ CNRS/UMR 5563, Université Paul Sabatier, France

$13{ }^{5}$ Earth Science, University College London, UK

$14 \quad{ }^{6}$ Reykjavik Energy, Iceland

$15{ }^{7}$ European Commission, Joint Research Center, Institute for Energy and Transport,

16 Petten, The Netherlands

$17{ }^{8}$ Iceland GeoSurvey, Reykjavik, Iceland

$18{ }^{9}$ Department of Applied Geology, Curtin University, Perth, Western Australia

$19{ }^{10}$ Nano-Science Center, Department of Chemistry, University of Copenhagen, Denmark

21 Carbon capture and storage (CCS) provides a solution towards decarbonization of the

22 global economy. The success of this solution depends on the ability to safely and 
23 permanently store $\mathrm{CO}_{2}$. This study demonstrates for the first time the permanent

24 disposal of $\mathrm{CO}_{2}$ as environmentally benign carbonate minerals in basaltic rocks. We

25 find that over $95 \%$ of the $\mathrm{CO}_{2}$ injected into the CarbFix site in Iceland was mineralized

26 to carbonate minerals in less than two years. This result contrasts with the common

27 view that the immobilization of $\mathrm{CO}_{2}$ as carbonate minerals within geologic reservoirs

28 takes several hundreds to thousands of years. Our results, therefore, demonstrate

29 that the safe long-term storage of anthropogenic $\mathrm{CO}_{2}$ emissions through

30 mineralization can be far faster than previously postulated.

32 The success of geologic $\mathrm{CO}_{2}$ storage depends on its long-term security and public

33 acceptance in addition to regulatory, policy, and economical factors (1). $\mathrm{CO}_{2}$ and brine

34 leakage through a confining system above the storage reservoir or through abandoned

35 wells is considered as one of the major challenges associated with geologic $\mathrm{CO}_{2}$ storage

36 [e.g. $(2,3,4)]$. Leakage rates into the atmosphere of $\leq 0.1 \%$ are required to ensure

37 effective climate change mitigation [e.g. $(5,6)$ ]. To avoid $\mathrm{CO}_{2}$ leakage, caprock integrity

38 needs to be evaluated and monitored (7). Leakage risk is further enhanced by induced

39 seismicity, which may open fluid flow pathways in the caprock (8). Mineral

40 carbonatization (i.e. the conversion of $\mathrm{CO}_{2}$ to carbonate minerals) via $\mathrm{CO}_{2}$-fluid-rock

41 reactions in the reservoir minimizes the risk of leakage and thus facilitates long-term

42 and safe carbon storage and public acceptance (9). The potential for carbonatization is,

43 however, limited in conventional $\mathrm{CO}_{2}$ storage reservoirs such as deep saline aquifers,

44 and depleted oil and gas reservoirs in sedimentary basins due to the lack of calcium, 
45 magnesium and iron rich silicate minerals required to form carbonate minerals $(10,11)$.

46 An alternative is to inject $\mathrm{CO}_{2}$ into basaltic rocks, which contain up to $25 \%$ by weight of

47 calcium, magnesium and iron. Basaltic rocks are highly reactive, and one of the most

48 common rock types on Earth, covering $\sim 10 \%$ of continental surface area and most of the

49 ocean floor [e.g. $(12,13)]$.

51 The CarbFix pilot project was designed to promote and verify in situ $\mathrm{CO}_{2}$ mineralization

52 in basaltic rocks for the permanent disposal of anthropogenic $\mathrm{CO}_{2}$ emissions (14). Two

53 injection tests were performed at the CarbFix injection site near the Hellisheidi

54 geothermal power plant: Phase I: 175 tons of pure $\mathrm{CO}_{2}$ from January to March 2012, and

55 Phase II: 73 tons of a $\mathrm{CO}_{2}-\mathrm{H}_{2} \mathrm{~S}$ gas mixture in June to August 2012, of which 55 tons were

$56 \mathrm{CO}_{2}$. Note that $\mathrm{H}_{2} \mathrm{~S}$ is not only a major constituent of geothermal gases but also of $\mathrm{CO}_{2}-$

57 rich sour gas. Since the cost of CCS is dominated by capture and gas separation, the

58 overall cost could be lowered substantially by injecting gas mixtures rather than pure

$59 \mathrm{CO}_{2}(9)$. Hence, the purpose of the mixed $\mathrm{CO}_{2} / \mathrm{H}_{2} \mathrm{~S}$ injection was to assess the feasibility

60 of injecting impurities in the $\mathrm{CO}_{2}$ stream.

61

62 The CarbFix injection site is situated about $25 \mathrm{~km}$ east of Reykjavik and equipped with a

$632000 \mathrm{~m}$ deep injection well (HNO2) and 8 monitoring wells ranging in depth from 150 to

$641300 \mathrm{~m}$ (Fig. 1). The target $\mathrm{CO}_{2}$ storage formation is between 400 and $800 \mathrm{~m}$ depth and

65 consists of basaltic lavas and hyaloclastites with lateral and vertical intrinsic

66 permeabilities of 300 and $1700 \times 10^{-15} \mathrm{~m}^{2}$, respectively $(15,16)$. It is overlain by low 
67 permeability hyaloclastites. The formation water temperature and $\mathrm{pH}$ in the injection

68 interval range from 20 to $33^{\circ} \mathrm{C}$ and from 8.4 to 9.4 , and it is oxygen depleted (15). Due to

69 the shallow depth of the target storage reservoir and the risk of $\mathrm{CO}_{2}$ gas leakage through

70 fractures, a novel $\mathrm{CO}_{2}$ injection system was designed and used, which dissolves the

71 gases into down-flowing water in the well during its injection (17). To avoid potential

72 degassing, $\mathrm{CO}_{2}$ concentration in the injected fluids was kept below its solubility at

73 reservoir conditions (17). Once dissolved in water, $\mathrm{CO}_{2}$ is no longer buoyant (17) and it

74 immediately starts to react with the Ca-Mg-Fe-rich reservoir rocks.

76 Since dissolved or mineralized $\mathrm{CO}_{2}$ cannot be detected by conventional monitoring

77 methods such as seismic imaging, the fate of the injected $\mathrm{CO}_{2}$ was monitored using a

78 suite of chemical and isotopic tracers. The injected $\mathrm{CO}_{2}$ was spiked with carbon-14 $\left({ }^{14} \mathrm{C}\right)$,

79 to monitor its transport and reactivity (18). For the pure $\mathrm{CO}_{2}$ and the $\mathrm{CO}_{2} / \mathrm{H}_{2} \mathrm{~S}$

80 injections, the ${ }^{14} \mathrm{C}$ concentrations of the injected fluids were $40.0 \mathrm{~Bq} / \mathrm{L}\left({ }^{14} \mathrm{C} /{ }^{12} \mathrm{C}: 2.16 \mathrm{x}\right.$

$\left.811^{-11}\right)$ and $6 \mathrm{~Bq} / \mathrm{L}\left({ }^{14} \mathrm{C} /{ }^{12} \mathrm{C}: 6.5 \times 10^{-12}\right)$, respectively. By comparison, the ${ }^{14} \mathrm{C}$ concentration

82 in the reservoir prior to the injections was $0.0006 \mathrm{~Bq} / \mathrm{L}\left({ }^{14} \mathrm{C} /{ }^{12} \mathrm{C}: 1.68 \times 10^{-13}\right)$. This novel

83 carbon tracking method was previously proposed for geologic $\mathrm{CO}_{2}$ storage monitoring

84 but its feasibility has not been tested previously $(19,20)$. As ${ }^{14} \mathrm{CO}_{2}$ behaves chemically

85 and physically identical as ${ }^{12} \mathrm{CO}_{2}$ and is only minimally affected by isotope fraction during

86 phase transitions (21) it provides the means to accurately inventory the fate of the

87 injected carbon.

88 
89 In addition to ${ }^{14} \mathrm{C}$, we continuously co-injected non-reactive but volatile sulfur

90 hexafluoride $\left(\mathrm{SF}_{6}\right)$ and trifluoromethyl sulfur pentafluoride $\left(\mathrm{SF}_{5} \mathrm{CF}_{3}\right)$ tracers to assess

91 plume migration in the reservoir. The $\mathrm{SF}_{6}$ was used during Phase I and $\mathrm{SF}_{5} \mathrm{CF}_{3}$ during

92 Phase II. The $\mathrm{SF}_{6}$ and $\mathrm{SF}_{5} \mathrm{CF}_{3}$ concentrations in the injected fluids were $2.33 \times 10^{-8}$

$93 \mathrm{ccSTP} / \mathrm{cc}$ and $2.24 \times 10^{-8} \mathrm{ccSTP} / \mathrm{cc}$, respectively.

94

95 The $\mathrm{CO}_{2}$ and $\mathrm{CO}_{2} / \mathrm{H}_{2} \mathrm{~S}$ mixtures, together with the tracers were injected into the target

96 storage formation fully dissolved in water pumped from a nearby well. Typical injection

97 rates during Phase I injection were $70 \mathrm{~g} / \mathrm{s}$ for $\mathrm{CO}_{2}$ and $1800 \mathrm{~g} / \mathrm{s}$ for $\mathrm{H}_{2} \mathrm{O}$, respectively

98 (17). Injection rates during Phase II varied between 10 and $50 \mathrm{~g} / \mathrm{s}$ for $\mathrm{CO}_{2}$ and 417 and

$992082 \mathrm{~g} / \mathrm{s}$ for $\mathrm{H}_{2} \mathrm{O}$. The dissolved carbon concentration (DIC) and pH of the injectates

100 were $0.82 \mathrm{~mol} / \mathrm{L}$ and $3.85\left(\right.$ at $20^{\circ} \mathrm{C}$ ) for Phase I and $0.43 \mathrm{~mol} / \mathrm{L}$ and 4.03 for Phase II. Fluid

101 samples for $\mathrm{SF}_{6}, \mathrm{SF}_{5} \mathrm{CF}_{3},{ }^{14} \mathrm{C}$, DIC and $\mathrm{pH}$ analyses were collected without degassing using

102 a specially designed downhole sampler from the injection well HNO2 (22) or with a

103 submersible pump from the first monitoring well HNO4 located ca. 70 m downstream

104 from HNO2 at 400 m depth below surface prior, during and post-injection (Tables S1 -

105 S3).

106

107 The arrival of the injectate from Phase I at the monitoring well HNO4 was confirmed by

108 an increase in $\mathrm{SF}_{6}$ concentration, and a sharp decrease in $\mathrm{pH}$ and DIC concentration (Fig.

$1092 \mathrm{~A}$ and $\mathrm{B}$, Table S3). Based on the $\mathrm{SF}_{6}$ data, the initial breakthrough in HNO4 occurred

11056 days after injection. Subsequently, the $\mathrm{SF}_{6}$ concentration slightly decreased before a 
111 further increase in concentration occurred, with peak concentration 406 days after

112 initiation of the injection. $\mathrm{SF}_{5} \mathrm{CF}_{3}$ behaves similarly (Fig. $2 \mathrm{~A}$ ); its initial arrival was

113 detected 58 days after initiation of the Phase II injection, followed by decreasing

114 concentrations until 350 days after the injection started. Subsequently, the $\mathrm{SF}_{5} \mathrm{CF}_{3}$

115 concentration increased, consistent with the $\mathrm{SF}_{6}$ tracer breakthrough curve. The double

116 peaks in these tracer breakthrough curves are also in agreement with results from

117 previous tracer tests showing that the storage formation consists of relatively

118 homogenous porous media intersected by a low volume and fast flow path that

119 channels about 3\% of the tracer flow between HNO2 and HNO4 (23).

121 The time series of $\mathrm{DIC}, \mathrm{pH}$, and ${ }^{14} \mathrm{C}$ in $\mathrm{HNO} 4$ are initially coincident with the $\mathrm{SF}_{6}$ record,

122 showing peak concentrations in ${ }^{14} \mathrm{C}$ and $\mathrm{DIC}$ and a decrease in $\mathrm{pH}$ around 56 days after

123 injection (Figs. $2 \mathrm{~B}$ and 3). The small drop in pH and increase in DIC around 200 days

124 after injection is caused by the Phase II injection as confirmed by the $\mathrm{SF}_{5} \mathrm{CF}_{3}$ time series

125 (Fig. 2 A). The similar initial pattern in the tracer breakthrough curves and the DIC

126 concentration suggests identical transport behavior of carbon and tracers in the

127 reservoir. However, ${ }^{14} \mathrm{C}$ and DIC concentrations subsequently decreased and stayed

128 more or less constant for the remaining monitoring period, with the exception of a small

129 increase in concentration induced by the Phase II injection (Figs. 2 B and 3 A and B).

131 The fate of the injected $\mathrm{CO}_{2}$ was quantified using mass balance calculations (18). 
132 The resulting calculated DIC and ${ }^{14} \mathrm{C}$ concentrations are much higher than that measured

133 in the collected water samples, suggesting a loss of DIC and ${ }^{14} \mathrm{C}$ along the subsurface

134 flow path towards the monitoring well (Fig. $3 \mathrm{~A}$ and $\mathrm{B}$ ). The most plausible mechanism

135 for this difference is carbonate precipitation. The differences between calculated and

136 measured DIC and ${ }^{14} \mathrm{C}$ indicate that $>95 \%$ of the injected $\mathrm{CO}_{2}$ was mineralized through

137 water- $\mathrm{CO}_{2}$-basalt reactions between the injection ( $\mathrm{HNO2}$ ) and monitoring (HNO4) wells

138 within two years (Fig. $3 \mathrm{~A}$ and $\mathrm{B}$ ). The initial peak concentrations in DIC and ${ }^{14} \mathrm{C}$ detected

139 around 56 days after injection suggest that travel time along the low volume fast

140 flowing flow path was too short for significant $\mathrm{CO}_{2}$ mineralization to occur. Most of the

141 injected $\mathrm{CO}_{2}$ was likely mineralized within the porous matrix of the basalt that allows for

142 longer fluid residence times and thus extended reaction time. This conclusion is

143 confirmed by 1) calculated fluid saturation states showing that the collected monitoring

144 fluids are at saturation or supersaturation with respect to calcite at all times except

145 during the initial low volume flow path contribution, 2) XRD and SEM-EDXS analysis of

146 secondary mineral precipitates collected from the submersible pump in monitoring well

147 HNO4 after it was hauled to the surface, showing these precipitates to be calcite (18)

148 (figs. $\mathrm{S} 1-\mathrm{S} 3$ ), and 3 ) the similarity in the ${ }^{14} \mathrm{C}$ concentration of the injected $\mathrm{CO}_{2}$ and the

149 precipitated collected calcite ( $7.48 \pm 0.8$ and $7.82 \pm 0.05$ fraction modern).

151 Although monitoring continues, the time scale of the tracer and DIC data discussed is

152 limited to 550 days since most of the injected $\mathrm{CO}_{2}$ was mineralized by this time (Figs. 2

153 and 3). This 550-day limit also coincides with the breakdown of the submersible pump in 
154 HNO4 monitoring well, which resulted in a 3-month gap in the subsequent monitoring

155 data. The pump was clogged and coated with calcite (18).

157 The fast conversion rate of dissolved $\mathrm{CO}_{2}$ to calcite minerals in the CarbFix storage

158 reservoir is most likely the result of several key processes: 1) The novel $\mathrm{CO}_{2}$ injection

159 system that injected water-dissolved $\mathrm{CO}_{2}$ into the subsurface; 2 ) The relatively rapid

160 dissolution rate of basalt, releasing $\mathrm{Ca}, \mathrm{Mg}$ and Fe ions required for the $\mathrm{CO}_{2}$

161 mineralization; (3) The mixing of injected water with alkaline formation waters; and (4)

162 The dissolution of pre-existing secondary carbonates at the onset of the $\mathrm{CO}_{2}$ injection,

163 which may have contributed to the neutralization of the injected $\mathrm{CO}_{2}$-rich water via the

164 reaction

$165 \mathrm{CaCO}_{3}+\mathrm{CO}_{2}+\mathrm{H}_{2} \mathrm{O}=\mathrm{Ca}^{2+}+2 \mathrm{HCO}_{3}^{-}$.

166 Dissolution of pre-existing calcite is supported by the ${ }^{14} \mathrm{C} /{ }^{12} \mathrm{C}$ ratio of the collected fluid

167 samples, which suggest a $50 \%$ dilution of the carbon in the fluid, most likely via calcite

168 dissolution just after it arrives in the basaltic reservoir. Nevertheless, the mass balance

169 calculations clearly demonstrate that these pre-existing carbonates re-precipitated

170 during the mineralization of the injected $\mathrm{CO}_{2}$.

171

172 The results of this study demonstrate that the nearly complete in-situ $\mathrm{CO}_{2}$

173 mineralization in basaltic rocks can occur in less than 2 years. Once stored within

174 carbonate minerals leakage risk is eliminated and any monitoring program of the

175 storage site can significantly be reduced thus enhancing storage security and potentially 
176 public acceptance. Note that natural aqueous fluids in basalts and those at the CarbFix

177 site tend to be at or close to equilibrium with respect to calcite, limiting its redissolution

178 (16). The upscaling of this basaltic carbon storage method requires substantial quantity

179 of water and porous basaltic rocks (9). Both are widely available on the continental

180 margins such as off the coast of the Pacific northwest of the United States (12).

181

182 References and Notes

183 1. B. Metz, O. Davidson, H. de Coninck, M. Loos, L. A. Meyer, Eds. IPCC Special

184 Report on Carbon Dioxide Capture and Storage (Cambridge Univ. Press, New

185 York, 2005).

186 2. A. Espisito, S. Benson, SPE 133603-MS (2010).

187 3. B. Ellis et al., Greenhouse Gases: Science and Technology 1(3), 248-260 (2011).

188 4. J. M. Bielicki, M. F. Pollak, J. P. Fitts, C. A. Peters, E. J. Wilson, Int. J. Greenh. Gas

189 Control 20, 272-284 (2014).

190 5. P. M. Haugan, F. Joos, Geophys. Res. Lett. 31, L18202 (2004).

191 6. B. Van der Zwaan, L. Smekens, Environ. Model Assess. 14, 135-148 (2009).

192 7. H. S. Eggleston et al., Eds. IPCC guidelines for national greenhouse gas

193 inventories - A primer (National Greenhouse Gas Inventories Programme, IGES,

194 Japan, 2008).

195 8. M. D. Zoback, S. M. Gorelick, PNAS 109(26), 10164-10168 (2012).

196 9. S. R. Gislason, E. H. Oelkers, Science 344, 373-344 (2014).

197 10. J. M. Matter, P.B. Kelemen, Nature Geoscience 2, 837-841 (2009).

198 11. S. M. V. Gilfillan et al., Nature 458, 614-618 (2009). 
12. D. S. Goldberg, T. Takahashi, A. L. Slagle, PNAS 105(29), 9920-9925 (2008).

200 13. B. P. McGrail et al., JGR 111, B12201 (2006).

201 14. S. R. Gislason et al., Int. J. Greenhouse Gas Control 4, 537-545 (2010).

202 15. H. A. Alfredsson et al., Int. J. Greenhouse Gas Control 12, 399-418 (2013).

203 16. E. S. Aradóttir et al., Int. J. Greenhouse Gas Control 9, 24-40 (2012).

204 17. B. Sigfusson et al., Int. J. Greenhouse Gas Control 37, 213-219 (2015).

205 18. Materials and methods are available as supplementary material on Science

$206 \quad$ Online.

207 19. P.P. Bachelor et al., J. Radioanal. Nucl. Chem. 277(1), 85-89 (2008).

208 20. K. S. Lackner, S. Brennan, Climatic Change 96, 357-378 (2009).

209 21. I. D. Clark, P. Fritz, Environmental Isotopes in Hydrogeology (Lewis Publisher, $210 \quad$ Boca Raton, New York, 1997).

211 22. H. A. Alfredsson, K. Mesfin, D. Wolff-Boenisch, Greenhouse Gas Sci. Technol. 5, 1-

$212 \quad 11(2015)$

213 23. M. Rezvani Khalilabad, G. Axelsson, S. Gislason, Mineral. Mag. 72(1), 121-125

214 (2008).

215 24. M. Stuiver, H. A. Polach, Radiocarbon 19(3), 355-363 (1977).

216 25. D. L. Parkhurst, C. A. J. Appelo, Description of input and examples for PHREEQC

217 version 3, U.S. Geological Survey Techniques and Methods, book 6, 497 pp. 218 (2013).

219 26. W. Stumm, J. J. Morgan, Aquatic Chemistry: Chemical equilibria and rates in 220 natural waters (third ed.), John Wiley \& Sons, New York, 1022 pp. (1996). 

235 (2009).

28. D. L. Graf, American Mineralogist 46, 1283 (1961).

224 29. S. A. Markgraf, R. J. Reeder, American Mineralogist 70, 590 (1985).

225 30. H. T. Schaef, B. P. McGrail, Appl. Geochem. 24, 980-987 (2009)

226 31. D. Wolff-Boenisch, S. Wenau, S. R. Gislason, E. H. Oelkers Geochem. Cosmochim. Acta 75, 5510-5525 (2011).

32. A. P. Gysi, A. Stefansson, Geochem. Cosmochim. Acta 81, 129-152 (2012).

33. I. Galeczka, D. Wolff-Boenisch, E. H. Oelkers, S. R. Gislason, Geochem. Cosmochim. Acta 126, 123-145 (2014).

34. P. Cubillas et al. Geochem. Cosmochim. Acta 69, 5459 (2005).

234 Acknowledgments: We acknowledge funding from Reykjavik Energy, U.S. Department

235 of Energy under Award Number DE-FE0004847 to J.M.M and M.S., the European

236 Commission through the projects CarbFix (EC coordinated action 283148), Min-GRO

237 (MC-RTN-35488), Delta-Min (PITN-GA-2008-215360) and $\mathrm{CO}_{2}$-REACT (EC Project 317235)

238 to S.R.G., E.H.O. and Reykjavik Energy, and Nordic fund 11029-NORDICCS, the Icelandic

239 GEORG Geothermal Research fund (09-02-001) to S.R.G and Reykjavik Energy. We thank

240 Trausti Kristinsson and Einar Örn Prastarsonfor for helping with sample collection in the

241 field. All data used in this study are included in the supplementary material. 


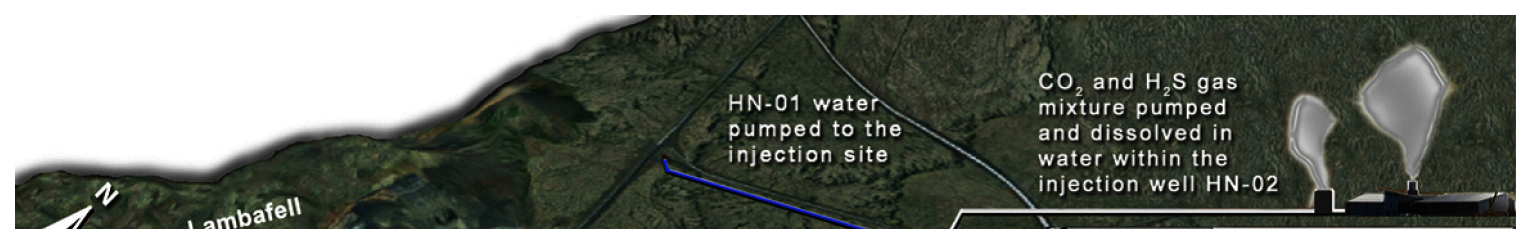

Fig. 1. Geological cross-section of the CarbFix injection site. $\mathrm{CO}_{2}$ and $\mathrm{H}_{2} \mathrm{~S}$ are injected samples for this study, where collected in $\mathrm{HNO} 2$ and the monitoring well HNO4

251 (modified from 15). 


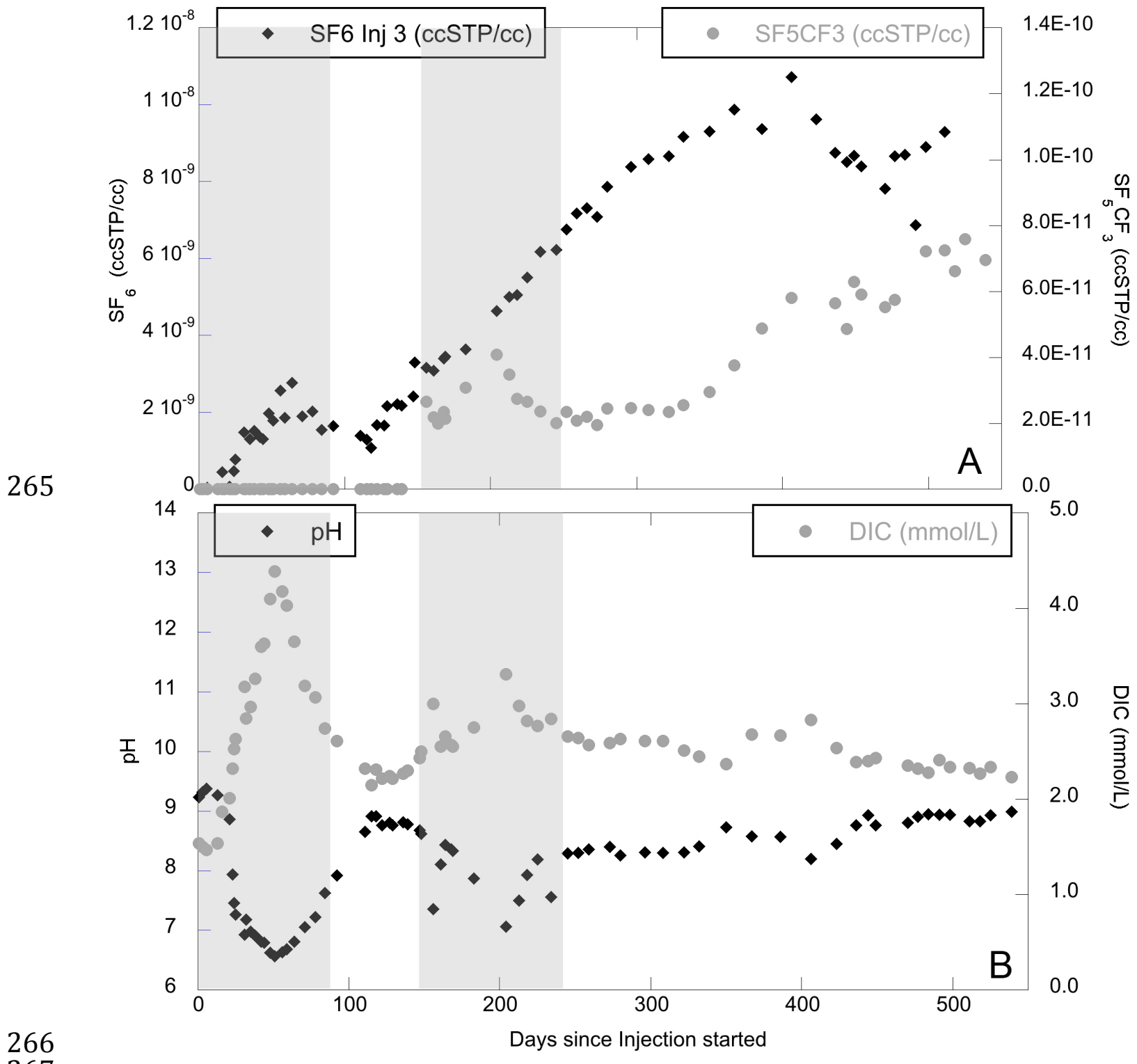

Fig. 2. Time series of (A) $\mathrm{SF}_{6}$ and $\mathrm{SF}_{5} \mathrm{CF}_{3}$ tracer concentrations (ccSTP/cc), and (B) pH and dissolved inorganic carbon (DIC) in monitoring well $\mathrm{HNO} 4$ for the pure $\mathrm{CO}_{2}$ and the $\mathrm{CO}_{2}$ \& $\mathrm{H}_{2} \mathrm{~S}$ injections. Shaded area indicates Phase I and II injection period. 

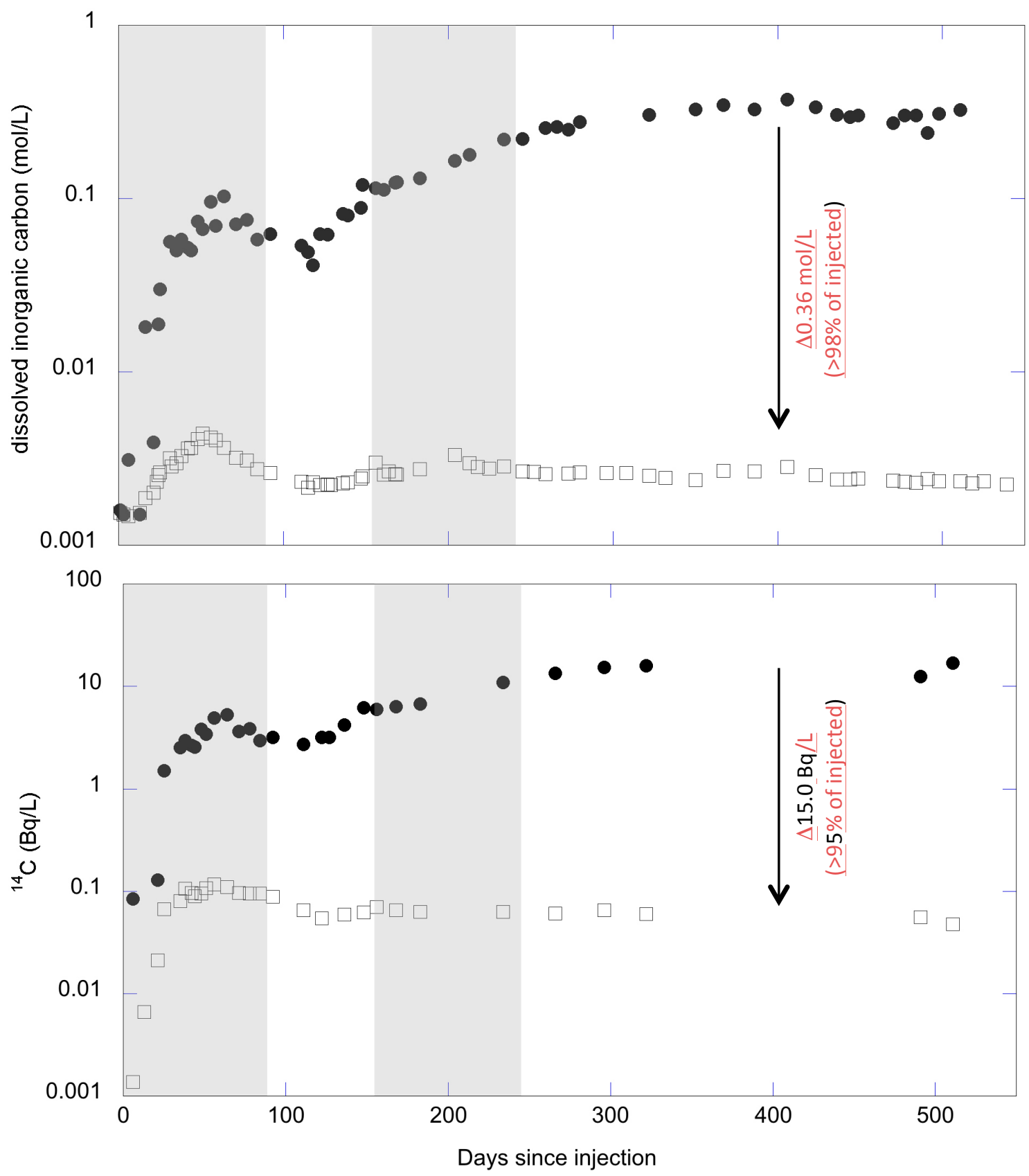

Fig. 3. (A) Time series of expected (full circles) vs. measured (empty squares) dissolved inorganic carbon (DIC, $\mathrm{mol} / \mathrm{L}$ ) in monitoring well HNO4, indicating $>98 \%$ conversion of injected $\mathrm{CO}_{2}$ to carbonate minerals, and (B) time series of expected (full circles) vs. measured (empty squares) ${ }^{14} \mathrm{C}_{\mathrm{DIC}}(\mathrm{Bq} / \mathrm{L})$ in monitoring well HNO4, showing $>95 \%$ of injected $\mathrm{CO}_{2}$ to be converted to carbonate minerals. Shaded area indicates Phase I and II 291 injection period.

292 


\section{Supplementary Materials for}

\section{Rapid carbon mineralization for permanent disposal of anthropogenic carbon dioxide emissions}

\section{Matter et al.}

Materials and Methods

Laboratory evidence of basalt carbonation

In-situ fluid chemistry and transport

Figs. S1-S3

Tables S1-S2

\section{Materials and Methods}

\section{1) The $\mathrm{SF}_{6}$ and $\mathrm{SF}_{5} \mathrm{CF}_{3}$ tracers}

$\mathrm{SF}_{6}$ and $\mathrm{SF}_{5} \mathrm{CF}_{3}$, originally stored in gas cylinders, were mixed into the $\mathrm{CO}_{2}$ and $\mathrm{CO}_{2}+\mathrm{H}_{2} \mathrm{~S}$ flue gas stream using mass flow controllers. Carbon-14 was added to the water injection stream as an aqueous $\mathrm{H}^{14} \mathrm{CO}_{3}{ }^{-}$solution using a Milton Roy micro-dosing pump (Model AA973-352S3). The $\mathrm{H}^{14} \mathrm{CO}_{3}{ }^{-}$solution was created by adding 10 $\mathrm{mCi}$ of a ${ }^{14} \mathrm{C}$-rich sodium bicarbonate aqueous solution obtained from Perkin Elmer to 100 liter of groundwater collected from the target storage reservoir prior to $\mathrm{CO}_{2}$ injection.

Fluid samples for $\mathrm{SF}_{6}$ and $\mathrm{SF}_{5} \mathrm{CF}_{3}$ analyses were collected in evacuated $100 \mathrm{ml}$ glass serum bottles from the monitoring well HNO4. Concentrations in the headspace were measured with a precision of $\pm 2 \%$ using gas chromatography (SRI 8610C) and ultrapure nitrogen as the carrier gas. The headspace samples were injected into a $6 \mathrm{ft}$ long, $1 / 8^{\prime \prime}$ wide pre-column with a 5 ångström molecular sieve (MS-5A) and a $6 \mathrm{ft}$ chromatographic column at $60^{\circ} \mathrm{C} . \mathrm{SF}_{6}$ and $\mathrm{SF}_{5} \mathrm{CF}_{3}$ concentrations were measured using a SRI $8610 \mathrm{C}$ gas chromatograph with an 
electron capture detector and a Alltech Carbograph column. Results were recorded using the PeakSimple 3.07.2 software, and concentrations in the water samples were calculated based on the volume of headspace and the solubility.

The $\mathrm{SF}_{6}$ concentration data from the Phase I injection had to be corrected for the $\mathrm{SF}_{6}$ that originated from a previous hydrological tracer test. In 2008 , we injected $\mathrm{SF}_{6}$ and sodium fluorescein (Na-Flu) into the target storage reservoir during a short duration tracer test to characterize the hydrology of the injection site. During the Phase I $\mathrm{CO}_{2}$ injection only $\mathrm{SF}_{6}$ was injected. Thus, the difference between the observed $\mathrm{Na}$-Flu and the $\mathrm{SF}_{6} / \mathrm{Na}$-Flu ratio can be used to calculate how much $\mathrm{SF}_{6}$ in the collected water samples is from the Phase I injection (Table S2). Without the addition from the Phase I injection, the $\mathrm{SF}_{6} / \mathrm{Na}$-Flu ratio would follow the trajectory of the Na-Flu concentration. Thus, multiplying the expected ratio by the observed Na-Flu concentration provides a measure of the expected $\mathrm{SF}_{6}$ concentration. The difference between the observed and expected $\mathrm{SF}_{6}$ concentration is the actual $\mathrm{SF}_{6}$ from the Phase I injection (Table $\mathrm{S} 2$ ).

\section{2) Carbon-14}

Fluid samples for ${ }^{14} \mathrm{C}$ analysis were collected in $125 \mathrm{ml}$ glass serum bottles. For ${ }^{14} \mathrm{C}$ analysis, water samples were acidified to release the dissolved inorganic carbon as $\mathrm{CO}_{2}$. The ${ }^{14} \mathrm{C}$ concentration was measured with ${ }^{14} \mathrm{C}$ AMS first in the W.M. Keck Carbon Cycle Accelerator Mass Spectrometry Laboratory at the University of California, Irvine, and later in the BioAMS laboratory at Lawrence Livermore National Laboratory, USA. Results are reported as fractions of the Modern Standard, $\Delta^{14} \mathrm{C}$, following the conventions of Stuiver and Polach (24). All results are corrected for isotopic fractionation with $\delta^{13} \mathrm{C}$ values measured on prepared samples using AMS spectrometer. Data and uncertainties are reported in Table S2.

\section{3) Dissolved inorganic carbon (DIC)}


Dissolved inorganic carbon (DIC) was calculated using PHREEQC (25) from measured pH, alkalinity, in-situ temperature and total dissolved element concentration measurements. The $\mathrm{pH}$ was determined in the field with a Eutech InstrumentsTM CyberScan pH 110 electrode calibrated using NBS standards, and verified in the laboratory a few hours after sampling with a Cole Parmer glass pH electrode. Alkalinity titration was performed using the Gran function to determine the end point of the titration (26). The concentration of major elements including $\mathrm{Si}, \mathrm{Ca}, \mathrm{K}, \mathrm{Mg}, \mathrm{Na}$, and $\mathrm{S}$ and the trace metals Fe and $\mathrm{Al}$ were determined by Inductively Coupled Plasma Optical Emission Spectrometry (ICP-OES) using an in-house multi-elements standard checked against the SPEX Certified Reference standard at the University of Iceland. The uncertainties on calculated DIC measurements are estimated to be $\pm 5 \%$

\section{4) Mass balance calculations}

Mass balance calculations for dissolved inorganic carbon and ${ }^{14} \mathrm{C}$ were performed to assess the reactivity of the injected $\mathrm{CO}_{2}$ (27). The mixing fraction between the injected solution (IS) and ambient groundwater (BW) was calculated for each extracted water sample (i) using

$\left[S F_{6}\right]_{i}=X\left[S F_{6}\right]_{I S}+(1-X)\left[S F_{6}\right]_{B W}$

with $X$ being the fraction of injected solution in the extracted water sample. The expected DIC and ${ }^{14} \mathrm{C}$ values due to pure mixing was then determined from

$D I C_{m i x}=X \cdot D I C_{I S}+(1-X) \cdot D I C_{B W}$

and

${ }^{14} C_{\text {mix }}=X \cdot{ }^{14} C_{I S}+(1-X) \cdot{ }^{14} C_{B W}$

Differences in DIC and ${ }^{14} \mathrm{C}$ concentrations between the values measured in the retrieved fluid samples and the expected values assuming only mixing between injectate and ambient groundwater yield the loss of DIC and

${ }^{14} \mathrm{C}$ due to carbonate precipitation. 


\section{5) Analysis of solid phases}

Mineral precipitate samples collected from the submersible pump in monitoring borehole HNO4 were analyzed by X-Ray diffraction (XRD), scanning electron microscopy (SEM), and energy dispersive X-ray spectroscopy (EDXS) mapping. Prior to analysis, the samples were stored and treated in an anaerobic chamber to minimize oxidation.

Samples for XRD were mounted on low background Si sample holders and covered with an X-ray transparent cup (Bruker) to decrease oxidation of the fine-grained material during measurement. Measurements were conducted on a Bruker D8 DISCOVER equipped with a LynxEye detector and a Co-source. Scan range was $5-80^{\circ}$ using a $0.05^{\circ}$ step size and a count time of $10 \mathrm{~s}$ per step. Two types of samples were prepared for SEM-EDXS. One set was mounted directly on the Al-sample stubs to avoid a carbon signal from carbon tape. The material was resuspended in anoxic ethanol and a drop of it transferred to the sample holder and left to dry. These samples were imaged by SEM using low vacuum $(60 \mathrm{~Pa})$ to minimize sample charging. For another set of samples, the Al-sample holders were covered with carbon tape and grains were picked from the samples and mounted upright to enable imaging of these grains perpendicular to the growth direction. These samples were sputter coated with Au and imaged under high vacuum $\left(4 \times 10^{-4} \mathrm{~Pa}\right)$ to resolved detailed morphological features. SEM/EDXS measurements were conducted on a FEI Quanta 3D FEG SEM equipped with an Oxford instrument X-max $20 \mathrm{~mm}^{2}$ EDXS detector having a nominal energy resolution of $0.125 \mathrm{keV}$ for MnK $\alpha$ (FWMH). During imaging, accelerating voltage was $20 \mathrm{KeV}$ and currents were $3.8 \mathrm{pA}$ for SEM imaging and 8 nA for EDXS mapping. In the EDXS maps, color intensity for an element is linearly correlated with the integrated intensity

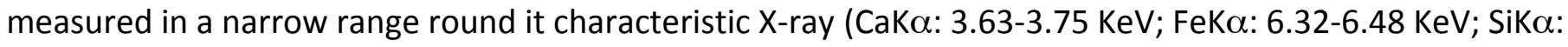

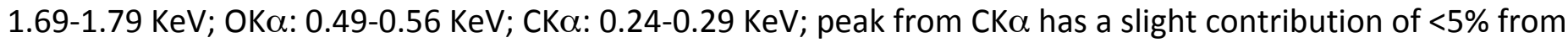
$A u_{N}$ lines). 
XRD of all materials from the monitoring borehole (Fig. S1) shows only the Bragg peaks expected for calcite [e.g. $(28,29)]$. Please note that the broad peaks between 10 and $30^{\circ}$ are from the cap protecting the sample from oxidation. SEM imaging and EDXS mapping clearly show $10 \mathrm{um}$ to $1 \mathrm{~mm}$ slightly elongated grains rich in $\mathrm{Ca}, \mathrm{C}$, and $\mathrm{O}$, as expected for calcite, with trace concentrations of $\mathrm{Mg}, \mathrm{Mn}$, and Fe (Fig. S2). Imaging of samples EDXS mapping of the grains collected from inside the pump shows a banded structure where they were fractured, with a first generation of calcite containing rich in Fe- and Si and a second generation largely without such material (Fig. S3).

\section{Laboratory studies of basalt carbonation.}

A large number of laboratory experiments have been performed to assess the feasibility of basalt carbonation as a carbon storage strategy (e.g. 15, 16, 30, 31, 32, 33). Such experiments demonstrate the efficient carbonation of basalts and its constituent minerals. During basalt-water- $\mathrm{CO}_{2}$ interaction, calcium liberated by basalt dissolution tends to provoke calcite precipitation, whereas the liberated magnesium, aluminum and silicon tend to provoke the formation of zeolite and clay minerals $(15,16,32)$.

Several experimental studies have been aimed at assessing if precipitated carbonate minerals would eventually slow the overall carbonation rates of basalts and its constituent minerals $(9,10)$. Such studies suggest that the carbonate minerals that precipitate on the surfaces of these rocks and minerals have little effect on the dissolution rates of the original solid and on their carbonation rates. These results were attributed to the poor structural match between the dissolving silicate and precipitating carbonate, which leaves sufficient pathways for chemical mass transfer to and from the adjoining fluid phase (e.g. 34). Such results suggest that the in-situ carbonation of basalts will be little effected by the precipitation of carbonate phases on their surfaces. 


\section{In situ fluid chemistry and transport}

Representative pre-injection fluid chemistries at the injection site are summarized in Table S2. The temperature gradient at the injection site is $80^{\circ} \mathrm{C} / \mathrm{km}$. Groundwater flow in the top tens of meters is to southwest (16); water flow in the lower part of the system is focused in lava flows located at the $\mathrm{CO}_{2}$ injection depth of 400-800 $\mathrm{m}$ depth. The flow rate in this lower system is on the order of $25 \mathrm{~m}$ per year and the hydraulic head decreases toward southwest $(15,16)$. Hydrological models, pump tests and tracer tests, suggest that the effective matrix porosity of this lava formation is $8.5 \%$ (16).

The injection of $\mathrm{CO}_{2}$-charged waters lead to a $\mathrm{pH}$ drop in the formation waters provoking the dissolution of basalt and the eventual precipitation of carbonate minerals. In addition to the natural ambient water flow in the target basaltic reservoir, advective transport in the system was enhanced by the continuous pumping of water into the $\mathrm{HN}-02$ injection well and pumping of water from the $\mathrm{HN}-04$ monitoring well at a rate of $1 \mathrm{l} / \mathrm{s}$ throughout the study period. The dominance of advection as the chemical transport mechanism in the system is evident in the concentration of chemical tracer in the monitoring fluid shown in Fig. 2; aqueous diffusion is far too slow to transport substantial material from the injection to the monitoring well over the 2year study period. 


\section{Supporting Tables}

Table S1. Injection test parameters, including results from the tracer and chemical analysis of injectate.

\begin{tabular}{|c|c|c|c|c|c|c|c|}
\hline $\begin{array}{c}\text { Injection } \\
\text { Phase }\end{array}$ & $\begin{array}{c}\mathrm{CO}_{2} \\
\text { (tons) }\end{array}$ & $\begin{array}{c}\mathrm{H}_{2} \mathrm{O} \\
\text { (liters) }\end{array}$ & $\begin{array}{c}\mathrm{SF}_{6} \\
\text { (ccSTP/cc) }\end{array}$ & $\begin{array}{c}\mathrm{SF}_{5} \mathrm{CF}_{3} \\
(\mathrm{ccSTP} / \mathrm{cc})\end{array}$ & $\begin{array}{c}{ }^{14} \mathrm{C} \\
\text { (fraction } \\
\text { modern })\end{array}$ & $\begin{array}{c}\mathrm{DIC} \\
\text { (mol/L) }\end{array}$ & $\mathrm{pH}$ \\
\hline $\mathrm{I}$ & 175 & $4.8 \times 10^{6}$ & $2.33 \times 10^{-8}$ & none & 16.17 & 0.82 & $\begin{array}{c}3.85 \\
\left(@ 20^{\circ} \mathrm{C}\right) \\
4.03 \\
\text { II }\end{array}$ \\
\hline
\end{tabular}


Table S2. Representative water chemistries at the CarbFix injection site prior to the gas injections (after 15).

\begin{tabular}{|c|c|c|c|}
\hline & \multicolumn{3}{|c|}{ Well } \\
\hline $\begin{array}{l}\text { Parameter or aqueous } \\
\text { concentration }\end{array}$ & $\begin{array}{c}\mathrm{HN}-1 \text { (source of injection } \\
\text { water) }\end{array}$ & $\mathrm{HN}-2$ & $\mathrm{HN}-4$ \\
\hline Sample & 08HAA02 & 09HAA16 & 08HAA01 \\
\hline Sampling date & 1 July 2008 & 19 May 2009 & 1 July 2008 \\
\hline Temperature ${ }^{\circ} \mathrm{C}$ & 19.0 & 15.5 & 32.3 \\
\hline $\mathrm{pH}$ at $20 \pm 2{ }^{\circ} \mathrm{C}$ & 8.87 & 8.79 & 9.43 \\
\hline $\mathrm{O}_{2}(\mathrm{mmol} / \mathrm{L})$ & 0.057 & 0.011 & 0.037 \\
\hline Alkalinity (meq/kg) & 1.91 & 1.45 & 1.91 \\
\hline $\mathrm{F}(\mathrm{mmol} / \mathrm{L})$ & 0.014 & 0.013 & 0.026 \\
\hline $\mathrm{Cl}(\mathrm{mm} / \mathrm{L})$ & 0.247 & 0.222 & 0.228 \\
\hline $\mathrm{SO}_{4}(\mathrm{mmol} / \mathrm{L})$ & 0.075 & 0.077 & 0.089 \\
\hline $\mathrm{Na}(\mathrm{mmol} / \mathrm{L})$ & 1.301 & 1.338 & 2.114 \\
\hline $\mathrm{K}(\mathrm{mmol} / \mathrm{L})$ & 0.027 & 0.012 & 0.019 \\
\hline $\mathrm{Ca}(\mathrm{mmol} / \mathrm{L})$ & 0.164 & 0.124 & 0.041 \\
\hline $\mathrm{Mg}(\mathrm{mmol} / \mathrm{L})$ & 0.313 & 0.149 & 0.005 \\
\hline $\mathrm{Fe}(\mu \mathrm{mol} /)$ & 0.016 & 0.399 & 0.064 \\
\hline $\mathrm{Al}(\mu \mathrm{mol} /)$ & 0.419 & 0.097 & 1.905 \\
\hline $\mathrm{Si}(\mathrm{mmol} / \mathrm{L})$ & 0.363 & 0.337 & 0.897 \\
\hline
\end{tabular}


Table S3: Result from the tracer and chemical fluid analyses.

\begin{tabular}{|c|c|c|c|c|c|c|c|c|c|c|}
\hline $\begin{array}{c}\text { Sample } \\
\text { ID }\end{array}$ & $\begin{array}{l}\text { Days since } \\
\text { injection } \\
\text { started }\end{array}$ & $\begin{array}{c}\text { Na-Flu } \\
\text { (g/L) }\end{array}$ & $\begin{array}{c}\mathrm{SF}_{6} \\
\text { (ccSTP/cc) }\end{array}$ & $\begin{array}{l}\mathrm{SF}_{6} \text { Phase I } \\
\text { (ccSTP/cc)* }\end{array}$ & $\begin{array}{c}\mathrm{SF}_{5} \mathrm{CF}_{3} \\
\text { Phase II } \\
\text { (ccSTP/cc) }\end{array}$ & $\mathrm{pH}$ & $\begin{array}{c}\text { DIC } \\
\text { (mmol/ } \\
\text { L) }\end{array}$ & $\begin{array}{l}{ }^{14} \mathrm{C} \text { (frac. } \\
\text { modern) }\end{array}$ & \pm & $\begin{array}{l}{ }^{14} \mathrm{C} \\
(\mathrm{Bq} / \mathrm{L})\end{array}$ \\
\hline 619 & 1 & $4.94 \mathrm{E}-05$ & $1.51 \mathrm{E}-09$ & $2.44 \mathrm{E}-12$ & & 9.24 & 1.54 & & & \\
\hline 621 & 2 & & $1.54 \mathrm{E}-09$ & & & & & & & \\
\hline 623 & 3 & $4.98 \mathrm{E}-05$ & $1.45 \mathrm{E}-09$ & & & 9.32 & 1.5 & & & \\
\hline 629 & 6 & $5.05 \mathrm{E}-05$ & $1.62 \mathrm{E}-09$ & $4.34 \mathrm{E}-11$ & & 9.38 & 1.47 & 0.3119 & 0.0008 & 0.001377 \\
\hline 643 & 13 & $5.15 \mathrm{E}-05$ & $1.56 \mathrm{E}-09$ & & & 9.27 & 1.54 & 1.328 & 0.002 & 0.006584 \\
\hline 651 & 16 & $5.15 \mathrm{E}-05$ & 2.09E-09 & $4.52 \mathrm{E}-10$ & & 8.98 & 1.87 & & & \\
\hline 655 & 18 & & $1.90 \mathrm{E}-09$ & & & & & & & \\
\hline 661 & 21 & $5.14 \mathrm{E}-05$ & $1.70 \mathrm{E}-09$ & $6.58 \mathrm{E}-11$ & & 8.86 & 2.01 & 3.5054 & 0.0049 & 0.02117 \\
\hline 665 & 23 & & $2.02 \mathrm{E}-09$ & & & 7.94 & 2.32 & & & \\
\hline 667 & 24 & $5.14 \mathrm{E}-05$ & 2.10E-09 & $4.70 \mathrm{E}-10$ & & 7.46 & 2.53 & & & \\
\hline 669 & 25 & $5.14 \mathrm{E}-05$ & $2.41 \mathrm{E}-09$ & $7.75 E-10$ & & 7.27 & 2.63 & 8.4908 & 0.0119 & 0.06685 \\
\hline 679 & 31 & $5.23 \mathrm{E}-05$ & $3.18 \mathrm{E}-09$ & $1.48 \mathrm{E}-09$ & & 6.93 & 3.18 & & & \\
\hline 681 & 32 & & $3.25 \mathrm{E}-09$ & & & 7.18 & 2.85 & & & \\
\hline 687 & 35 & $5.36 \mathrm{E}-05$ & 3.09E-09 & $1.31 \mathrm{E}-09$ & & 6.98 & 2.97 & 9.0563 & 0.0217 & 0.08001 \\
\hline 693 & 38 & $5.43 \mathrm{E}-05$ & $3.35 \mathrm{E}-09$ & $1.52 \mathrm{E}-09$ & & 6.91 & 3.26 & 10.8941 & 0.0516 & 0.10575 \\
\hline 699 & 42 & $5.54 \mathrm{E}-05$ & $3.26 \mathrm{E}-09$ & $1.36 \mathrm{E}-09$ & & 6.81 & 3.6 & 9.8633 & 0.0338 & 0.09663 \\
\hline 703 & 44 & $5.46 \mathrm{E}-05$ & $3.16 \mathrm{E}-09$ & $1.31 \mathrm{E}-09$ & & 6.79 & 3.63 & 9.2766 & 0.0647 & 0.08921 \\
\hline 705 & 48 & $5.00 \mathrm{E}-05$ & $3.52 \mathrm{E}-09$ & 1.97E-09 & & 6.63 & 4.1 & 9.1683 & 0.0641 & 0.09506 \\
\hline 709 & 49 & & $3.70 \mathrm{E}-09$ & & & & & & & \\
\hline 715 & 51 & $4.92 \mathrm{E}-05$ & $3.27 \mathrm{E}-09$ & $1.78 \mathrm{E}-09$ & & 6.57 & 4.39 & 9.908 & 0.0758 & 0.10749 \\
\hline 721 & 56 & $4.90 \mathrm{E}-05$ & 4.05E-09 & $2.57 \mathrm{E}-09$ & & 6.64 & 4.18 & 10.9666 & 0.0696 & 0.11732 \\
\hline 723 & 59 & $4.90 \mathrm{E}-05$ & $3.34 \mathrm{E}-09$ & $1.86 \mathrm{E}-09$ & & 6.68 & 4.03 & & & \\
\hline 733 & 64 & $4.88 \mathrm{E}-05$ & 4.24E-09 & $2.78 \mathrm{E}-09$ & & 6.81 & 3.65 & 11.1269 & 0.0637 & 0.10968 \\
\hline 741 & 71 & $4.86 \mathrm{E}-05$ & $3.36 \mathrm{E}-09$ & $1.91 \mathrm{E}-09$ & & 7.06 & 3.19 & 10.3135 & 0.0805 & 0.09608 \\
\hline 747 & 78 & $4.85 \mathrm{E}-05$ & $3.47 \mathrm{E}-09$ & 2.03E-09 & & 7.22 & 3.07 & 10.963 & 0.089 & 0.09488 \\
\hline 753 & 84 & $4.83 \mathrm{E}-05$ & 2.99E-09 & $1.55 \mathrm{E}-09$ & & 7.63 & 2.74 & 10.963 & 0.089 & 0.09488 \\
\hline 763 & 92 & $5.03 E-05$ & $3.21 \mathrm{E}-09$ & $1.65 \mathrm{E}-09$ & & 7.92 & 2.61 & 11.2236 & 0.1119 & 0.08778 \\
\hline 775 & 111 & $5.51 \mathrm{E}-05$ & $3.28 \mathrm{E}-09$ & $1.40 \mathrm{E}-09$ & & 8.65 & 2.32 & 9.0533 & 0.052 & 0.06502 \\
\hline 777 & 115 & $4.96 \mathrm{E}-05$ & $2.81 \mathrm{E}-09$ & $1.30 \mathrm{E}-09$ & & 8.92 & 2.15 & & & \\
\hline 781 & 118 & $4.90 \mathrm{E}-05$ & $2.56 \mathrm{E}-09$ & $1.08 \mathrm{E}-09$ & & 8.92 & 2.31 & & & \\
\hline 783 & 122 & $4.85 \mathrm{E}-05$ & $3.12 \mathrm{E}-09$ & 1.67E-09 & & 8.76 & 2.22 & 8.0588 & 0.0616 & 0.05473 \\
\hline 785 & 127 & 4.74E-05 & $3.04 \mathrm{E}-09$ & $1.66 \mathrm{E}-09$ & & 8.81 & 2.24 & & & \\
\hline 787 & 129 & $4.70 \mathrm{E}-05$ & $3.52 \mathrm{E}-09$ & $2.16 \mathrm{E}-09$ & & 8.76 & 2.22 & & & \\
\hline 789 & 136 & 4.57E-05 & $3.49 \mathrm{E}-09$ & $2.21 \mathrm{E}-09$ & & 8.82 & 2.27 & 8.6288 & 0.0795 & 0.05938 \\
\hline 793 & 139 & $4.50 \mathrm{E}-05$ & $3.41 \mathrm{E}-09$ & 2.17E-09 & & 8.78 & 2.3 & & & \\
\hline 797 & 147 & $4.29 \mathrm{E}-05$ & $3.53 \mathrm{E}-09$ & $2.41 \mathrm{E}-09$ & & 8.68 & 2.43 & & & \\
\hline 801 & 148 & $4.29 \mathrm{E}-05$ & $4.42 \mathrm{E}-09$ & 3.30E-09 & & 8.62 & 2.5 & 8.4219 & 0.0742 & 0.06251 \\
\hline 803 & 149 & & 4.04E-09 & & & & & & & \\
\hline 813 & 156 & 4.16E-05 & 4.22E-09 & 3.17E-09 & $2.66 \mathrm{E}-11$ & 7.36 & 3 & 8.0027 & 0.0593 & 0.06998 \\
\hline
\end{tabular}




\begin{tabular}{|c|c|c|c|c|c|c|c|c|c|c|}
\hline 819 & 161 & 4.18E-05 & 4.15E-09 & 3.09E-09 & $2.18 \mathrm{E}-11$ & 8.11 & 2.55 & & & \\
\hline 825 & 164 & & 4.19E-09 & & $1.99 \mathrm{E}-11$ & 8.43 & 2.66 & & & \\
\hline 831 & 168 & 4.00E-05 & 4.37E-09 & 3.40E-09 & $2.35 \mathrm{E}-11$ & 8.36 & 2.57 & 8.4363 & 0.0521 & 0.06516 \\
\hline 833 & 169 & 3.90E-05 & 4.37E-09 & $3.45 \mathrm{E}-09$ & 2.14E-11 & 8.33 & 2.55 & & & \\
\hline 841 & 183 & 3.78E-05 & $4.50 \mathrm{E}-09$ & $3.64 \mathrm{E}-09$ & 3.09E-11 & 7.87 & 2.75 & 7.769 & 0.0512 & 0.0628 \\
\hline 847 & 204 & 3.64E-05 & $5.43 \mathrm{E}-09$ & 4.64E-09 & $4.09 \mathrm{E}-11$ & 7.07 & 3.31 & & & \\
\hline 849 & 213 & 3.60E-05 & $5.78 \mathrm{E}-09$ & 5.01E-09 & $3.49 \mathrm{E}-11$ & 7.50 & 2.98 & & & \\
\hline 850 & 218 & $3.56 \mathrm{E}-05$ & $5.81 \mathrm{E}-09$ & 5.06E-09 & $2.75 \mathrm{E}-11$ & 7.93 & 2.82 & & & \\
\hline 851 & 225 & $3.51 \mathrm{E}-05$ & $6.23 \mathrm{E}-09$ & 5.50E-09 & $2.65 \mathrm{E}-11$ & 8.19 & 2.77 & & & \\
\hline 853 & 234 & $3.42 \mathrm{E}-05$ & 6.87E-09 & 6.17E-09 & $2.36 \mathrm{E}-11$ & 7.56 & 2.84 & 7.9298 & 0.0512 & 0.06267 \\
\hline 855 & 245 & 3.37E-05 & $6.90 \mathrm{E}-09$ & $6.22 \mathrm{E}-09$ & $2.01 \mathrm{E}-11$ & 8.29 & 2.66 & & & \\
\hline 857 & 252 & 3.34E-05 & $7.42 \mathrm{E}-09$ & 6.76E-09 & $2.35 \mathrm{E}-11$ & 8.30 & 2.64 & & & \\
\hline 858 & 259 & $3.34 \mathrm{E}-05$ & $7.84 \mathrm{E}-09$ & $7.18 \mathrm{E}-09$ & $2.08 \mathrm{E}-11$ & 8.36 & 2.57 & & & \\
\hline 859 & 266 & $3.26 \mathrm{E}-05$ & $7.94 \mathrm{E}-09$ & $7.32 \mathrm{E}-09$ & $2.20 \mathrm{E}-11$ & & & 7.4848 & 0.0776 & 0.06051 \\
\hline 860 & 273 & $3.21 \mathrm{E}-05$ & $7.69 \mathrm{E}-09$ & $7.08 \mathrm{E}-09$ & $1.95 \mathrm{E}-11$ & 8.40 & 2.59 & & & \\
\hline 861 & 280 & 3.09E-05 & $8.42 \mathrm{E}-09$ & 7.86E-09 & $2.45 \mathrm{E}-11$ & 8.26 & 2.63 & & & \\
\hline 863 & 296 & $3.00 \mathrm{E}-05$ & $8.92 \mathrm{E}-09$ & 8.39E-09 & $2.46 \mathrm{E}-11$ & 8.31 & 2.61 & 8.4791 & 0.0742 & 0.06498 \\
\hline 865 & 308 & 2.94E-05 & $9.09 \mathrm{E}-09$ & $8.58 \mathrm{E}-09$ & $2.42 \mathrm{E}-11$ & 8.30 & 2.61 & & & \\
\hline 869 & 322 & $2.92 \mathrm{E}-05$ & $9.15 \mathrm{E}-09$ & 8.66E-09 & $2.35 \mathrm{E}-11$ & 8.31 & 2.51 & 8.3668 & 0.0657 & 0.06009 \\
\hline 873 & 332 & $2.88 \mathrm{E}-05$ & $9.65 \mathrm{E}-09$ & $9.17 \mathrm{E}-09$ & $2.56 \mathrm{E}-11$ & 8.41 & 2.45 & & & \\
\hline 875 & 350 & $2.88 \mathrm{E}-05$ & $9.79 \mathrm{E}-09$ & $9.31 \mathrm{E}-09$ & $2.96 \mathrm{E}-11$ & 8.73 & 2.37 & & & \\
\hline 877 & 367 & 2.69E-05 & $1.03 \mathrm{E}-08$ & $9.88 \mathrm{E}-09$ & $3.77 \mathrm{E}-11$ & 8.58 & 2.68 & & & \\
\hline 879 & 386 & $2.47 \mathrm{E}-05$ & $9.72 \mathrm{E}-09$ & $9.37 \mathrm{E}-09$ & $4.88 \mathrm{E}-11$ & 8.57 & 2.67 & & & \\
\hline 881 & 406 & $2.31 \mathrm{E}-05$ & $1.10 \mathrm{E}-08$ & 1.07E-08 & $5.81 \mathrm{E}-11$ & 8.20 & 2.83 & & & \\
\hline 883 & 423 & $2.33 \mathrm{E}-05$ & $9.94 \mathrm{E}-09$ & $9.63 \mathrm{E}-09$ & $5.65 \mathrm{E}-11$ & 8.45 & 2.54 & & & \\
\hline 881 & 436 & $2.26 \mathrm{E}-05$ & $9.03 \mathrm{E}-09$ & 8.75E-09 & $4.87 \mathrm{E}-11$ & 8.76 & 2.39 & & & \\
\hline 889 & 444 & 2.15E-05 & 8.77E-09 & $8.52 \mathrm{E}-09$ & $6.30 \mathrm{E}-11$ & 8.93 & 2.4 & & & \\
\hline 893 & 449 & 2.17E-05 & 8.93E-09 & 8.67E-09 & $5.92 \mathrm{E}-11$ & 8.76 & 2.43 & & & \\
\hline 895 & 454 & 2.15E-05 & $8.65 \mathrm{E}-09$ & $8.40 \mathrm{E}-09$ & $5.52 \mathrm{E}-11$ & & & & & \\
\hline 897 & 470 & 2.13E-05 & 8.07E-09 & $7.82 \mathrm{E}-09$ & $5.76 \mathrm{E}-11$ & 8.81 & 2.35 & & & \\
\hline 901 & 477 & 2.09E-05 & $8.90 \mathrm{E}-09$ & 8.66E-09 & & 8.91 & 2.32 & & & \\
\hline 905 & 484 & $2.05 \mathrm{E}-05$ & 8.93E-09 & 8.70E-09 & & 8.95 & 2.28 & & & \\
\hline 907 & 491 & $1.92 \mathrm{E}-05$ & 7.07E-09 & 6.87E-09 & & 8.94 & 2.41 & 7.5505 & 0.0467 & 0.05559 \\
\hline 909 & 498 & $1.92 \mathrm{E}-05$ & $9.10 \mathrm{E}-09$ & 8.91E-09 & & 8.94 & 2.34 & & & \\
\hline 913 & 511 & $2.20 \mathrm{E}-05$ & $9.57 \mathrm{E}-09$ & $9.30 \mathrm{E}-09$ & $7.26 \mathrm{E}-11$ & 8.83 & 2.33 & 6.5517 & 0.0472 & 0.04745 \\
\hline 915 & 518 & & $8.28 \mathrm{E}-09$ & & $6.61 \mathrm{E}-11$ & 8.83 & 2.27 & 6.2029 & & 0.04231 \\
\hline 917 & 525 & & $9.80 \mathrm{E}-09$ & & $7.59 \mathrm{E}-11$ & 8.93 & 2.34 & 7.2165 & & 0.05075 \\
\hline 918 & 539 & & 9.39E-09 & & $6.96 \mathrm{E}-11$ & 8.99 & 2.23 & 6.6135 & & 0.04571 \\
\hline
\end{tabular}




\section{Supporting Figures}

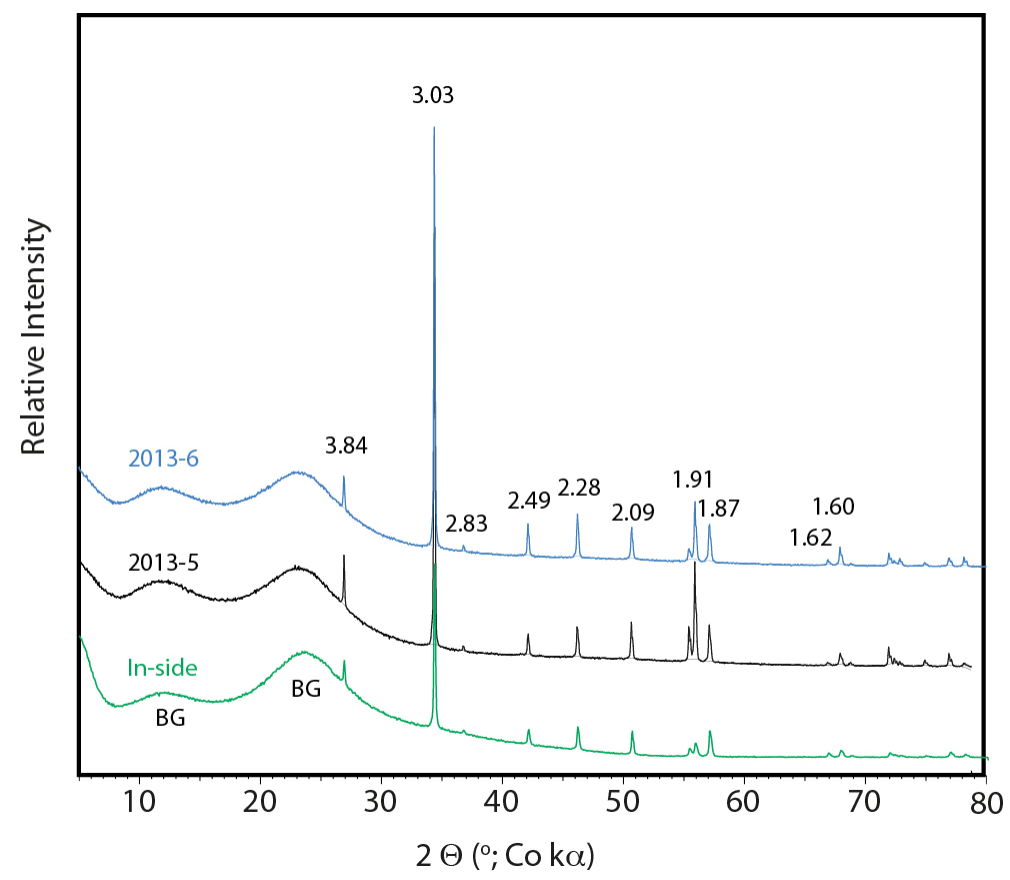

Figure S1. X-ray tracers of sample 2013-5 and 2013-6 taken from the submersible pump. The two broad peaks are from the cap protecting the sample from further oxidation is marked BG.
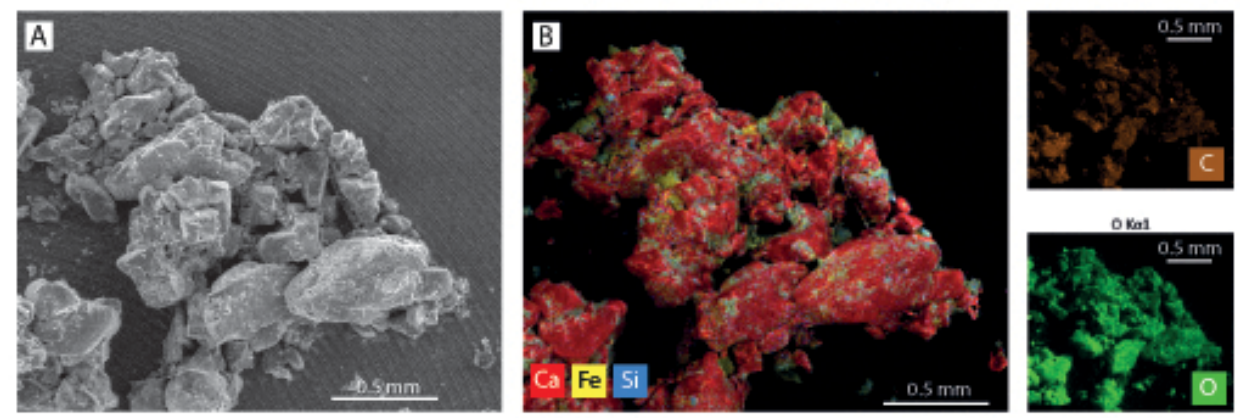

Figure S2. Overview SEM images and EDX maps of material from sample 2013-6. (A) SEM image. (B) EDX map of are shown in SEM image A. The maps for $\mathrm{Ca}, \mathrm{Fe}$ and $\mathrm{Si}$ has been overlain the SEM image, whereas the maps for $\mathrm{C}$ and $\mathrm{O}$ are presented individually. 

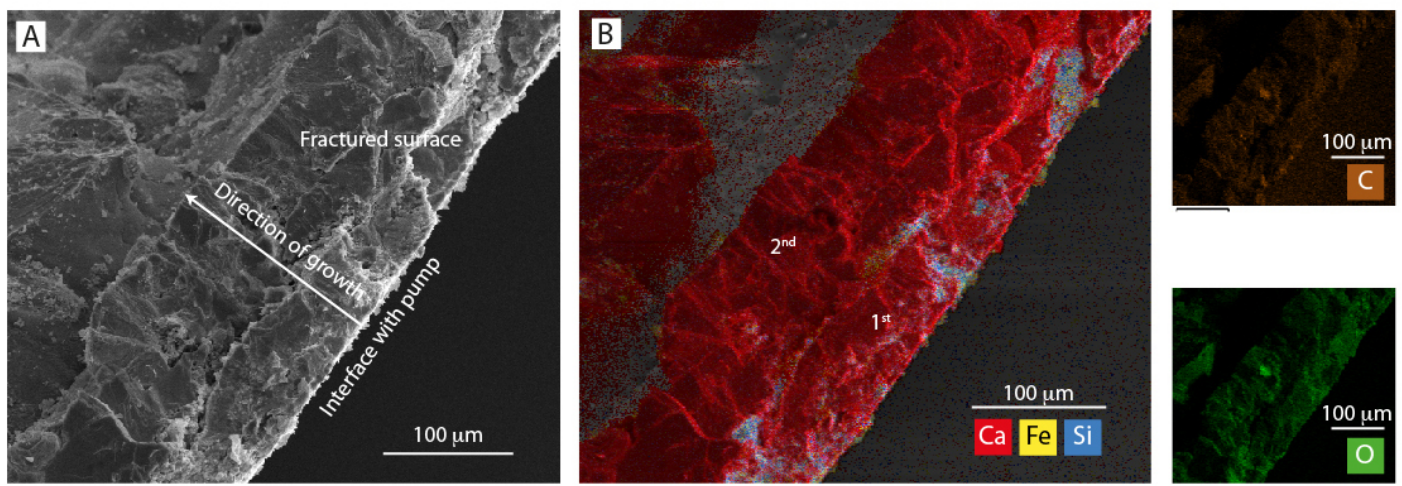

Figure S3. SEM images and EDX maps of fractured flake from a sample collected inside the submersible pump. (A) SEM image of the fractured flake mounted upright so that the internal regions of the material could be imaged. Fractured region, where the material interfaced with the pump surface and the direction of mineral growth is indicated. (B) EDX maps of area shown in SEM image A. The maps for Ca, Fe and $\mathrm{Si}$ has been overlain the SEM image, whereas the maps for $\mathrm{C}$ and $\mathrm{O}$ are presented individually. The location of two generations of calcite have been indicated based on the frequency of Fe- and Si-rich material. 